\title{
Migraine, Stroke, and Cervical Arterial Dissection
}

Shared Genetics for a Triad of Brain Disorders With Vascular Involvement

Neurol Genet 2022;8:e663. doi:10.1212/NXG.0000000000000663

In the Article "Migraine, Stroke, and Cervical Arterial Dissection: Shared Genetics for a Triad of Brain Disorders With Vascular Involvement" by Daghlas et al., ${ }^{1}$ the first author's name should be listed as "Iyas Daghlas," and the last author's name should be listed as "Daniel I. Chasman" in the byline and in Appendix 1. The authors and editorial staff regret the errors.

\section{Reference}

1. Daghals I, Sargurupremraj M, Danning R, et al. Migraine, stroke, and cervical arterial dissection: shared genetics for a triad of brain disorders with vascular involvement. Neurol Genet, 2022;8(1):e653. 


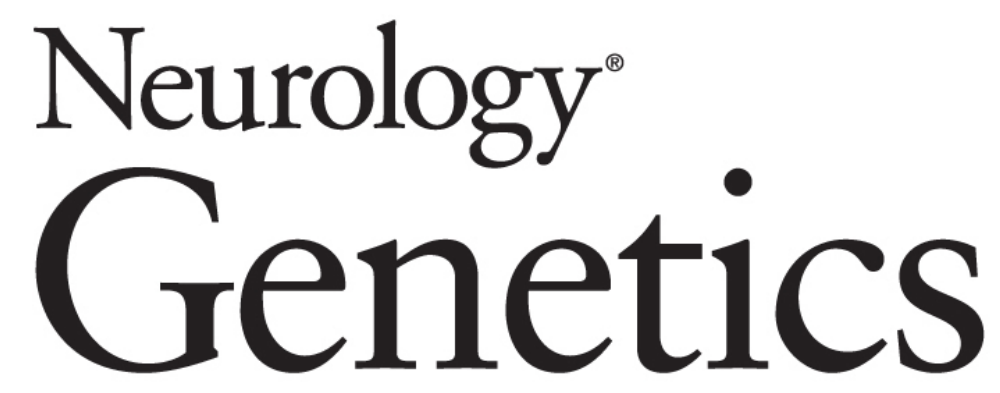

\title{
Migraine, Stroke, and Cervical Arterial Dissection: Shared Genetics for a Triad of Brain Disorders With Vascular Involvement \\ Neurol Genet 2022;8; \\ DOI 10.1212/NXG.0000000000000663
}

This information is current as of February 21, 2022

\begin{abstract}
Updated Information \& Services

including high resolution figures, can be found at: http://ng.neurology.org/content/8/2/e663.full.html

References

This article cites 1 articles, 0 of which you can access for free at: http://ng.neurology.org/content/8/2/e663.full.html\#\#ref-list-1

Subspecialty Collections

This article, along with others on similar topics, appears in the following collection(s):

Mitochondrial disorders

http://ng.neurology.org//cgi/collection/mitochondrial_disorders Mitochondrial disorders; see Genetics/Mitochondrial disorders http://ng.neurology.org//cgi/collection/mitochondrial_disorders_see_ge netics-mitochondrial_disorders

Permissions \& Licensing

Information about reproducing this article in parts (figures,tables) or in its entirety can be found online at:

http://ng.neurology.org/misc/about.xhtml\#permissions

Reprints

Information about ordering reprints can be found online: http://ng.neurology.org/misc/addir.xhtml\#reprintsus
\end{abstract}

Neurol Genet is an official journal of the American Academy of Neurology. Published since April 2015, it is an open-access, online-only, continuous publication journal. Copyright @ 2022 American Academy of Neurology. All rights reserved. Online ISSN: 2376-7839.

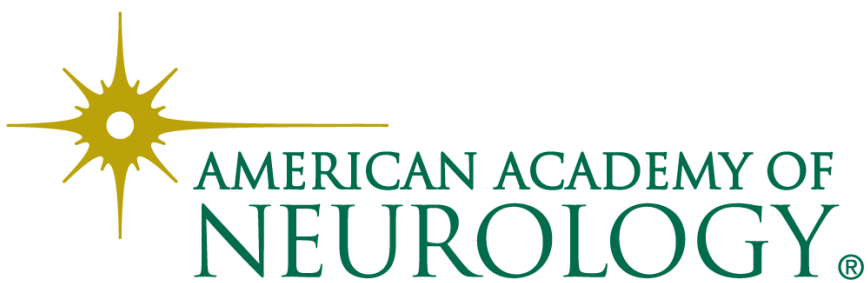

